\title{
Utility of fine needle aspiration cytology in head and neck lesions and its correlation with histopathology- a study in tertiary care hospital
}

\author{
Sushma Thapa ${ }^{1}$, Arnab Ghosh ${ }^{1}$, Dilasma Ghartimagar ${ }^{1}$, Sudeep Regmi ${ }^{1}$, OP Talwar ${ }^{1}$ \\ ${ }^{\prime}$ Department of Pathology, Manipal Teaching Hospital, Pokhara, Nepal
}

\author{
Keywords: \\ Fine Needle Aspiration \\ Cytology; \\ Head and neck lesions; \\ Thyroid;
}

\begin{abstract}
Background: Fine Needle Aspiration Cytology has rapidly gained acceptance due to the easy accessibility of target sites and minimally invasive nature. It is a very simple, quick, cost-effective method of sampling alternative to the time-consuming complicated, and invasive excision biopsy. The study aimed to access the utility of fine-needle aspiration cytology in the diagnosis of various head and neck lesions and also to establish the diagnostic accuracy between the cytological and histopathological diagnosis.
\end{abstract}

Materials and Methods: A retrospective observational study of 380 cases of FNACs on head and neck swellings performed in various age groups in the Department of Pathology of a tertiary care hospital from January 2018 to December 2019.

Results: Out of 380 patients, the maximum number of cases were seen in the thyroid (40.8\%), followed by lymph nodes $(39.5 \%)$, skin, soft tissue, miscellaneous $(10.8 \%)$, and salivary glands $(8.9 \%)$. Benign and non-neoplastic cases outnumbered $(88.1 \%)$ the malignant $(10.8 \%)$ cases. Histopathological followup was available in $28(7.4 \%)$ cases among which $25(89.3 \%)$ cases were consistent with the cytodiagnosis. The sensitivity, specificity, and diagnostic accuracy were evaluated to be $80 \%, 94.4 \%$, and $89.3 \%$ respectively.

Conclusion: The majority of the cases of head and neck swellings were seen in the thyroid followed by lymph nodes, skin, soft tissue, miscellaneous, and salivary glands. In thyroid, colloid goiter and papillary carcinoma were the commonest benign and malignant lesions respectively. In the lymph node, reactive lymphadenitis, and metastatic squamous cell carcinoma were the commonest benign and malignant lesions respectively.

\section{Correspondence:}

Dr. Sushma Thapa, MD

Assistant Professor, Department of Pathology

Manipal Teaching Hospital, Pokhara, Nepal

ORCID ID: 0000-0002-1303-9065

Email: sushmathp@hotmail.com

Reveived : July $22^{\text {nd }} 2020$; Accepted : September $26^{\text {th }} 2020$

Citation: Thapa S, Ghosh A, Ghartimagar D, Regmi S, Talwar OP. Utility of Fine Needle Aspiration Cytology in head and neck lesions and its correlation with histopathology- A study in tertiary care hospital. J Pathol Nep 2020;10:1733-41. DOI: 10.3126/jpn.v10i2.30255

Copyright: This is an open-access article distributed under the terms of the Creative Commons Attribution 4.0 International License, which permits unrestricted use, distribution, and reproduction in any medium, provided the original author and source are credited.

\section{INTRODUCTION}

Fine Needle Aspiration Cytology (FNAC), first introduced by Martin in 1930, has gained acceptance due to its simple, quick, cost-effective method of sampling. ${ }^{1,2}$ FNAC is useful in early differentiation of benign from malignant pathology and thus avoids time-consuming invasive excision biopsy., ${ }^{3,4}$ It is widely used in the head and neck swellings such as in the lymph nodes, thyroid, major salivary glands, and other neoplastic lesions. ${ }^{5-7}$ The present study aims to assess the utility of FNAC in the diagnosis of head and neck lesions and to establish the diagnostic accuracy of cytology by comparing it with histopathological diagnosis. 


\section{MATERIALS AND METHODS}

A retrospective observational study was conducted in the Department of Pathology, Manipal Teaching Hospital, Pokhara, a tertiary care hospital, from January 2018 to December 2019. Ethical clearance was obtained from the Institutional Review Committee. That patient who presented with superficially palpable head and neck lesions in the department of Medicine, Surgery, and Dermatology or admitted in the hospital and underwent FNAC was considered as the study group. Whereas, the cytological cases with descriptive findings and those with inadequate samplings were excluded from the study group.

After explaining to the patients about the procedure and its indications, a relevant clinical history was taken and information on radiological and laboratory investigations was noted. We tried our best to reassure the patients about the safety, simplicity of the procedure and explained to them about the minimal discomfort it would cause. FNA of the swelling was then performed by first cleaning the area to be aspirated with spirit. Then, a 22 or 23 gauge needle with a $10 \mathrm{ml}$ syringe was inserted at convenient angles. Multiple hits were made within the lesion, with sufficient negative pressure. The needle was then removed and the pressure was applied to the area of aspiration to avoid bleeding or hematoma formation. In some of the cases, no negative pressure was required at all. The aspirated material was then smeared on the clean glass slides using a glass spreader. The smeared slides were either air-dried or wet-dried as per the staining procedure adopted and stained by May-GrunwaldGiemsa (MGG) and Papanicolaou (Pap) stain respectively. Special stains like Ziehl Neelsen (ZN) stains were carried out as and when required. Cytological findings studied under the light microscope were reported. Biopsies obtained
Table 1: Distribution of head and neck lesions according to age-group and nature of the lesion

\begin{tabular}{lcccc}
\hline $\begin{array}{l}\text { Age-group } \\
\text { (years) }\end{array}$ & Benign (n) & $\begin{array}{c}\text { Malignant } \\
(\mathbf{n})\end{array}$ & $\begin{array}{c}\text { Suspicious } \\
(\mathbf{n})\end{array}$ & Total (n) \\
\hline $\mathbf{0 - 1 0}$ & 25 & 0 & 0 & 25 \\
$\mathbf{1 1 - 2 0}$ & 36 & 2 & 1 & 39 \\
$\mathbf{2 1 - 3 0}$ & 56 & 3 & 0 & 59 \\
$\mathbf{3 1 - 4 0}$ & 52 & 6 & 0 & 58 \\
\hline $\mathbf{4 1 - 5 0}$ & 60 & 9 & 1 & 70 \\
\hline $\mathbf{5 1 - 6 0}$ & 46 & 5 & 0 & 51 \\
\hline $\mathbf{6 1 - 7 0}$ & 36 & 6 & 2 & 44 \\
\hline $\mathbf{7 1 - 8 0}$ & 18 & 8 & 0 & 26 \\
\hline$>\mathbf{8 0}$ & 6 & 2 & 0 & 8 \\
\hline Total & $\mathbf{3 3 5}$ & $\mathbf{4 1}$ & $\mathbf{4}$ & $\mathbf{3 8 0}$ \\
\hline
\end{tabular}

from those patients for histopathological study were fixed in $10 \%$ buffered formalin and processed. Different sections so obtained were stained with Hematoxylin and Eosin (H\&E) stain and special stains were applied as and when required. Data were processed and analyzed using SPSS version 17.

\section{RESULTS}

A total of 380 cases involving the head and neck region were included in the study group, among which 118 (31.1\%) were males and $262(68.9 \%)$ were females with male to female ratio being 1:2.2. In this study, the age range of the patient was between one month to 89 years with a mean of 41.8 years. The peak incidence was noted in the fourth decade 70 (18.4\%) followed by the second decade $59(15.5 \%)$ and the third decade $58(15.3 \%)$ as shown in Table 1.

The maximum number of aspirates was from the thyroid $(n=155,40.8 \%)$ followed by lymph nodes $(n=150$,

Table 2: Distribution of lesions of thyroid according to cytological diagnosis and gender

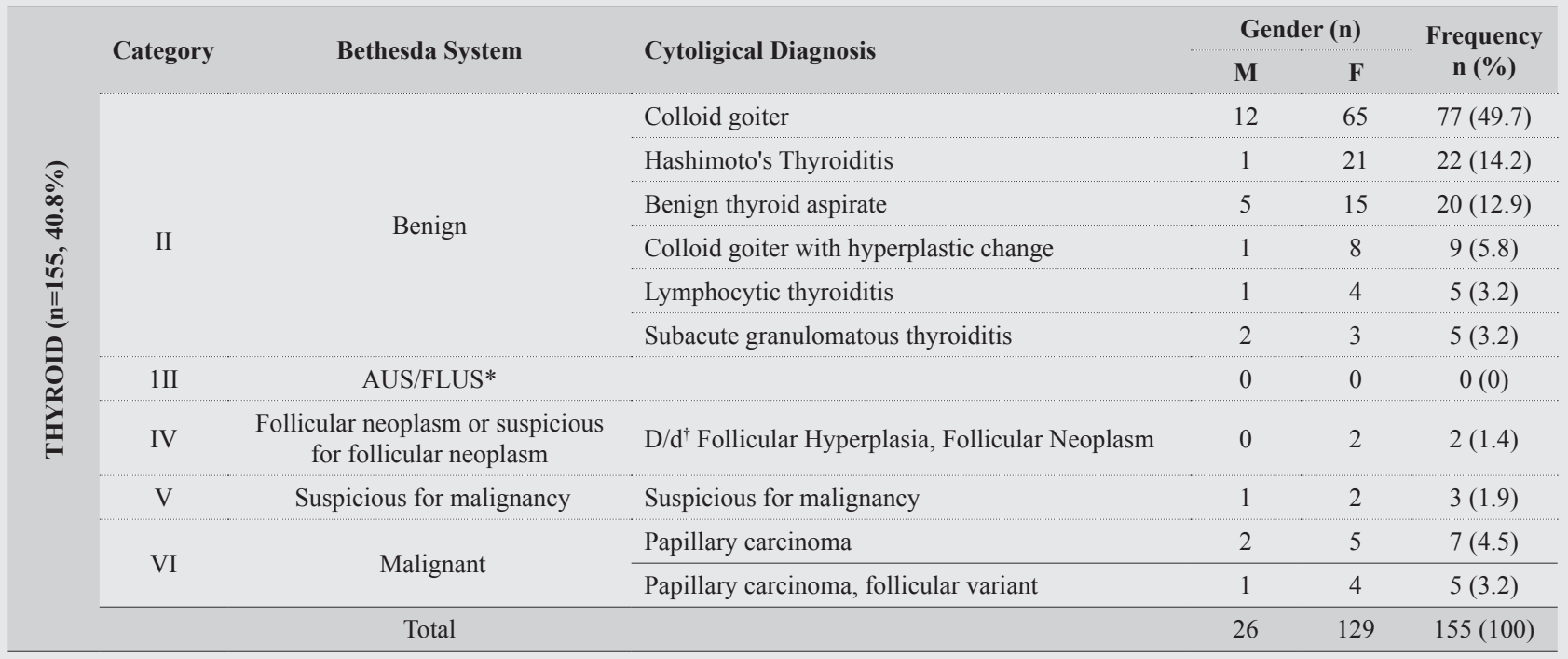

*AUS/FLUS - Atypia of Undetermined Significance / Follicular Lesion of Undetermined Significance; ${ }^{\dagger} D / d$ - Differential diagnosis 
Table 3: Distribution of lesions of salivary gland according to cytological diagnosis and gender

\begin{tabular}{|c|c|c|c|c|c|c|}
\hline \multirow{14}{*}{ 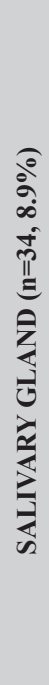 } & \multirow{2}{*}{ Category } & \multirow{2}{*}{ Milan System } & \multirow{2}{*}{ Cytoligical Diagnosis } & \multicolumn{2}{|c|}{ Gender (n) } & \multirow{2}{*}{$\begin{array}{c}\text { Frequency } \\
\text { n (\%) }\end{array}$} \\
\hline & & & & M & $\mathbf{F}$ & \\
\hline & \multirow{4}{*}{ II } & \multirow{4}{*}{ Non-neoplastic $(\mathrm{n}=18,52.9 \%)$} & Benign aspirate & 0 & 8 & $8(23.5)$ \\
\hline & & & Chronic sialadenitis & 2 & 3 & $5(14.7)$ \\
\hline & & & Intra-parotid lymphadenitis & 1 & 2 & $3(8.8)$ \\
\hline & & & Abscess & 0 & 2 & $2(5.9)$ \\
\hline & $1 \mathrm{II}$ & AUS & & 0 & 0 & $0(0)$ \\
\hline & \multirow{2}{*}{ IV } & \multirow{2}{*}{ Benign $(n=11,32.4 \%)$} & Pleomorphic adenoma & 3 & 7 & $10(29.4)$ \\
\hline & & & Warthin's tumor & 0 & 1 & $1(2.9)$ \\
\hline & $\mathrm{V}$ & $\begin{array}{l}\text { Suspicious for malignancy } \\
\qquad(\mathrm{n}=1,1 \%)\end{array}$ & Suspicious for malignancy & 0 & 1 & $1(2.9)$ \\
\hline & \multirow{3}{*}{ VI } & \multirow{3}{*}{ Malignant $(\mathrm{n}=4,11.8 \%)$} & Malignant salivary gland tumor & 0 & 2 & $2(5.8)$ \\
\hline & & & Adenoid cystic carcinoma & 1 & 0 & $1(2.9)$ \\
\hline & & & Muco epidermoid carcinoma & 1 & 0 & $1(2.9)$ \\
\hline & & Total & & 8 & 26 & $34(100)$ \\
\hline
\end{tabular}

${ }^{*}$ AUS - Atypia of Undetermined Significance

Table 4: Distribution of lymph node lesions according to the cytological diagnosis and gender

\begin{tabular}{|c|c|c|c|c|c|c|}
\hline & \multirow{2}{*}{$\begin{array}{l}\text { Nature of } \\
\text { lesions }\end{array}$} & & \multirow{2}{*}{ Cytodiagnosis } & \multicolumn{2}{|c|}{ Gender (n) } & \multirow{2}{*}{$\begin{array}{c}\text { Frequency } \\
\text { n (\%) }\end{array}$} \\
\hline \multirow{9}{*}{ 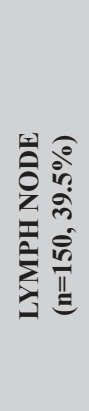 } & & & & M & $\mathbf{F}$ & \\
\hline & \multirow{4}{*}{$\begin{array}{c}\text { BENIGN } \\
(\mathrm{n}=123,82 \%)\end{array}$} & NON-INFECTIOUS & $\mathrm{RL}^{*}$ & 29 & 50 & $79(52.7)$ \\
\hline & & \multirow{3}{*}{ INFECTIOUS } & $\mathrm{TB}_{\mathrm{LN}}^{\dagger}$ & 8 & 13 & $21(14.0)$ \\
\hline & & & Abscess & 7 & 6 & $13(8.7)$ \\
\hline & & & Granulomatous lymphadenitis & 6 & 4 & $10(6.7)$ \\
\hline & \multirow{3}{*}{$\begin{array}{l}\text { MALIGNANT } \\
(\mathrm{n}=27,18 \%)\end{array}$} & & Mets $\mathrm{Ca}^{\ddagger}$ & 9 & 9 & $18(12.0)$ \\
\hline & & & $\mathrm{HL}^{\S}$ & 4 & 1 & $5(3.3)$ \\
\hline & & & $\mathrm{NHL}^{\|}$ & 2 & 2 & $4(2.6)$ \\
\hline & \multicolumn{3}{|c|}{ Total } & 65 & 85 & $150(100)$ \\
\hline
\end{tabular}

*RL-reactive lymphadenitis; ${ }^{*} T B$ LN-Tuberculous lymphadenitis; ${ }^{*}$ Mets Ca-Metastatic carcinoma; ${ }^{\$} H L-H o d g k i n ' s ~ l y m p h o m a ; " N H L-N o n-H o d g k i n ' s$ lymphoma;

Table 5: Distribution of skin, soft tissue, and miscellaneous lesions according to the cytological diagnosis and gender

\begin{tabular}{|c|c|c|c|c|c|}
\hline \multirow{2}{*}{\multicolumn{2}{|c|}{ Nature of lesions }} & \multirow{2}{*}{ Cytodiagnosis } & \multicolumn{2}{|c|}{ Gender (n) } & \multirow{2}{*}{$\begin{array}{l}\text { Frequency n } \\
\quad(\%)\end{array}$} \\
\hline & & & M & $\mathbf{F}$ & \\
\hline \multirow{12}{*}{ 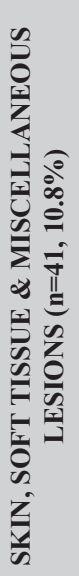 } & \multirow{5}{*}{$\begin{array}{c}\text { NON-NEOPLASTIC }(\mathrm{N}=23 \text {, } \\
56.1 \%)\end{array}$} & Epidermal cyst & 4 & 4 & $8(19.5)$ \\
\hline & & Thyroglossal cyst & 3 & 5 & $8(19.5)$ \\
\hline & & Benign aspirate & 3 & 2 & $5(12.2)$ \\
\hline & & Abscess & 1 & 0 & $1(2.4)$ \\
\hline & & Fibromatosis colli & 1 & 0 & $1(2.4)$ \\
\hline & \multirow{5}{*}{ BENIGN $(\mathrm{n}=14,34.1 \%)$} & $\mathrm{BLL}^{\pi}$ & 3 & 6 & $9(22.0)$ \\
\hline & & Spindle cell lesion & 2 & 0 & 2 \\
\hline & & Carotid body tumor & 0 & 1 & $1(2.4)$ \\
\hline & & Pilomatricoma & 0 & 1 & $1(2.4)$ \\
\hline & & Schwannoma & 1 & 0 & $1(2.4)$ \\
\hline & \multirow{2}{*}{ MALIGNANT (n=4, 9.8\%) } & Mets $\mathrm{Ca}^{* *}$ & 0 & 3 & $3(7.30$ \\
\hline & & Positive for Sarcoma & 1 & 0 & $1(2.40$ \\
\hline & Total & & 19 & 22 & $41(100)$ \\
\hline
\end{tabular}

${ }^{\circledR} B L L-$ Benign lipomatous lesion; **Mets Ca-Metastatic carcinoma. 
Table 6: Correlation between cytological and histological diagnosis of head and neck lesions

\begin{tabular}{|c|c|c|c|c|c|}
\hline SITE & $\begin{array}{c}\text { CASES } \\
\text { UNDERGONE } \\
\text { HPE* (n) }\end{array}$ & $\begin{array}{l}\text { CONSISTENT } \\
\text { (n) }\end{array}$ & $\begin{array}{c}\text { INCONSISTENT } \\
\text { (n) }\end{array}$ & CYTODIAGNOSIS (n) & HISTODIAGNOSIS (n) \\
\hline \multirow{3}{*}{ THYROID } & \multirow{3}{*}{4} & \multirow{3}{*}{4} & \multirow{3}{*}{0} & Colloid Goiter=2 & Colloid Goiter=2, \\
\hline & & & & $\begin{array}{l}\mathrm{CG} \dagger \text { with hyperplastic } \\
\text { change }=1\end{array}$ & $\begin{array}{l}\text { CG with hyperplastic } \\
\text { change }=1\end{array}$ \\
\hline & & & & $\begin{array}{l}\text { Pap } \mathrm{Ca} \ddagger \text {-follicular } \\
\text { variant=1 }\end{array}$ & $\begin{array}{l}\text { Pap Ca-follicular } \\
\text { variant }=1\end{array}$ \\
\hline \multirow{3}{*}{ LYMPH NODE } & \multirow{3}{*}{12} & \multirow{3}{*}{11} & \multirow{3}{*}{1} & $\begin{array}{l}\text { Granulomatous } \\
\text { lymphadenitis=5 }\end{array}$ & $\mathrm{TB} \mathrm{LN} \S=5$ \\
\hline & & & & $\mathrm{NHL} \|=4$ & $\mathrm{NHL}=3, \mathrm{METS} / \mathrm{NHL} \Phi=1$ \\
\hline & & & & $\mathrm{HL}=3$ & $\mathrm{HL}^{* *}=3$ \\
\hline \multirow{5}{*}{$\begin{array}{l}\text { SKIN, SOFT TISSUE } \\
\text { \& MISCELLANEOUS }\end{array}$} & \multirow{5}{*}{7} & \multirow{5}{*}{7} & \multirow{5}{*}{0} & Epidermal cyst $=2$ & Epidermal cyst $=2$ \\
\hline & & & & Thyroglossal Cyst=2 & Thyroglossal Cyst=2 \\
\hline & & & & $\mathrm{BLL} \dagger \dagger=1$ & Lipoma=1 \\
\hline & & & & Spindle cell lesion $=1$ & Neurofibroma $=1$ \\
\hline & & & & Positive for Sarcoma=1 & OSt+ $=1$ \\
\hline \multirow{3}{*}{ SALIVARY GLAND } & \multirow{3}{*}{5} & \multirow{3}{*}{3} & \multirow{3}{*}{2} & $\begin{array}{l}\text { Pleomorphic } \\
\text { adenoma }=3\end{array}$ & Pleomorphic adenoma $=3$ \\
\hline & & & & Abscess $=1$ & $\begin{array}{l}\text { Benign Lymphoepithelial } \\
\text { Cyst }=1\end{array}$ \\
\hline & & & & $\begin{array}{l}\text { Malignant salivary gland } \\
\text { tumor=1 }\end{array}$ & $\begin{array}{l}\text { Cellular Pleomorphic } \\
\text { adenoma }=1\end{array}$ \\
\hline Total & $28(7.4 \%)$ & $25(89.3 \%)$ & $3(10.7 \%)$ & & \\
\hline
\end{tabular}

HPE - Histopathological Examination; † CG - Colloid goiter; + Pap Ca - Papillary Carcinoma; $\$ T B$ LN - Tuberculous Lymphadenitis; ||NHL - Non-

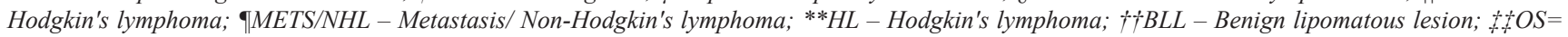
Osteosarcoma

$39.5 \%)$, skin, soft tissue, miscellaneous $(\mathrm{n}=41,10.8 \%)$ and salivary glands $(\mathrm{n}=34,8.9 \%)$. Overall, benign and non-neoplastic cases were more common $(n=335,88.1 \%)$ than the malignant $(\mathrm{n}=41,10.8 \%)$ cases with four cases (1.1\%) showing suspicious for malignancy. The majority of the benign and non-neoplastic lesions were prevalent in the age groups below 40 years $(n=169,50.4 \%)$ whereas the malignant $(\mathrm{n}=30,73.2 \%)$ and suspicious lesions $(\mathrm{n}=3$,
$75 \%$ ) were seen predominantly in the age groups above 40 years. In all the sites, there was a female predominance with thyroid being the highest (5:1).

Thyroid cytopathology was classified according to the Bethesda System of Reporting. Accordingly, Category II included benign conditions comprising of 138 cases (89.1\%) among which colloid goiter was the commonest

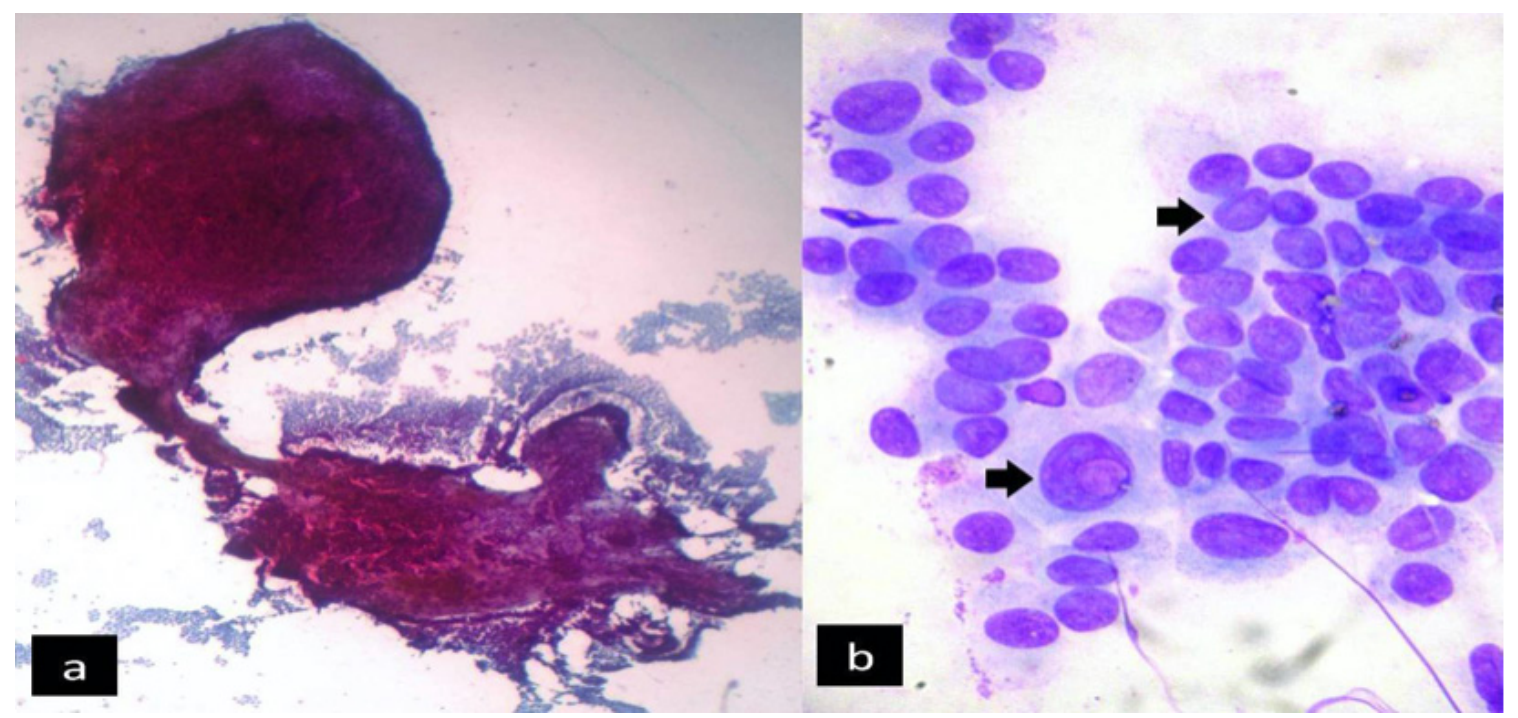

Figure 1: Cytosmears of papillary carcinoma thyroid showing (a) tumor cells in the papillary pattern (Pap stain, x40) (b) Black arrows show intranuclear cytoplasmic inclusion and nuclear grooving (MGG stain, x400) 


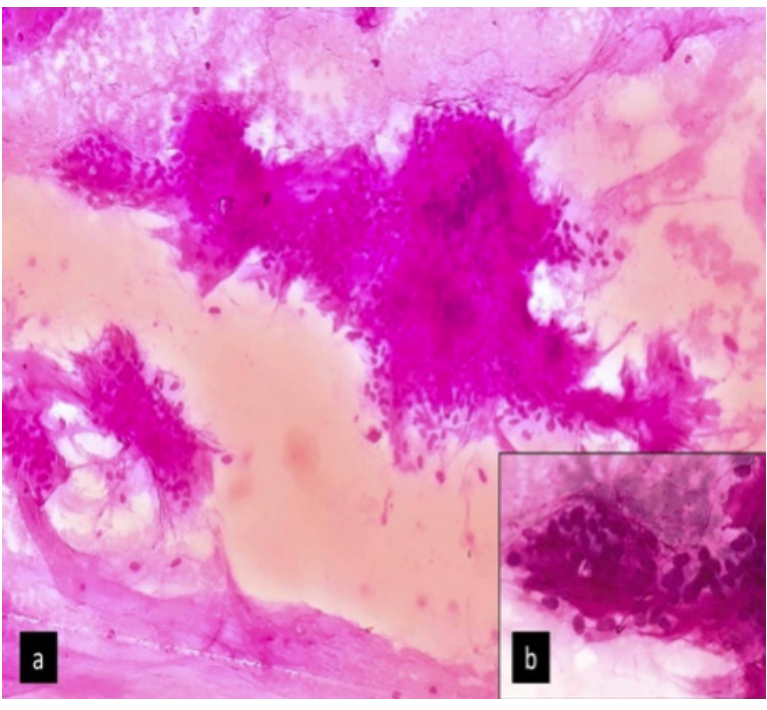

Figure 2: (a) Cytosmear of pleomorphic adenoma showing chondromyxoid matrix and myoepithelial cells (MGG stain, x100); (b) Inset shows myoepithelial cells (MGG stain,x400)

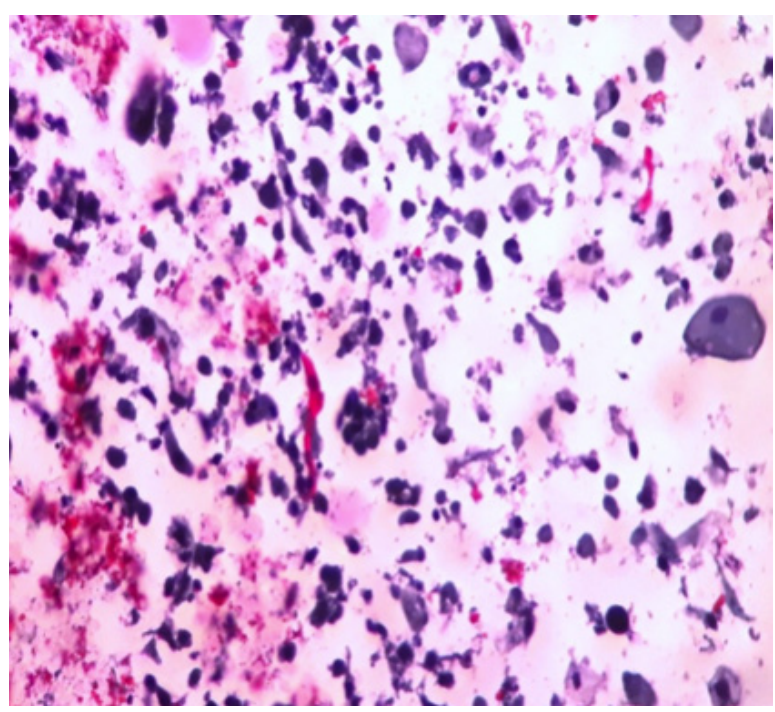

Figure 4: Cytosmear of metastatic squamous cell carcinoma showing malignant squamous cells (Pap stain, x100)

$(\mathrm{n}=77,49.7 \%)$ lesion. There were 12 (7.7\%) malignant cases in the thyroid and all of them were papillary carcinoma thyroid (PCT; fig. 1) among which five cases were papillary carcinoma thyroid, follicular variant (PCT-FV) (Table 2). Among the 155 cases of thyroid swelling, only four cases were available for histopathology and all the cases were consistent with the cyto-diagnosis among which three cases were benign viz. colloid goiter $(\mathrm{n}=2)$ and colloid goiter with hyperplastic change $(n=1)$, and one case was malignant i.e. PCT-FV.

The salivary gland cytopathology was categorized according to the Milan System of reporting. Category I comprises inadequate samples that were not included in the present study. Accordingly, Category II included 18 cases (52.9\%)

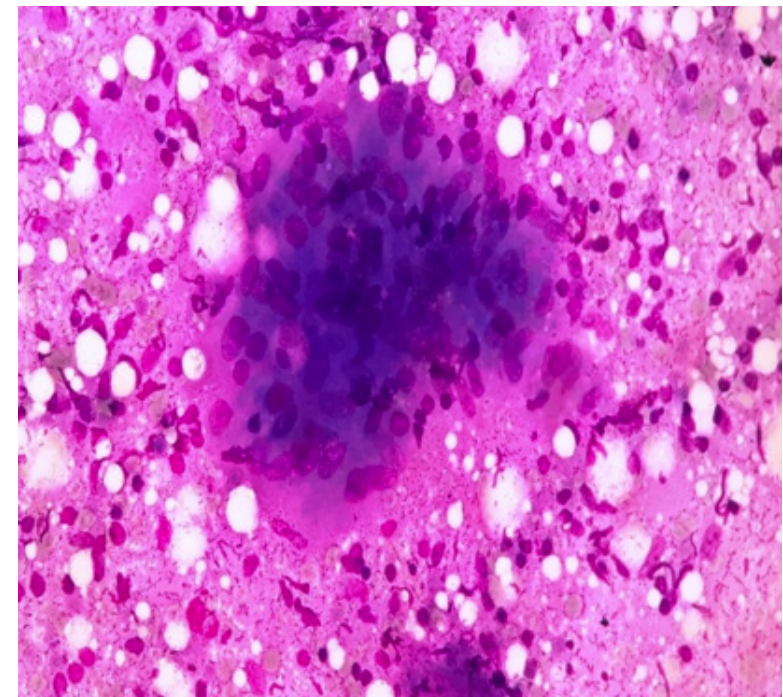

Figure 3: Cytosmear of tuberculous lymphadenitis showing epithelioid cell granuloma against a background of lymphoid cells (MGG stain, x400)

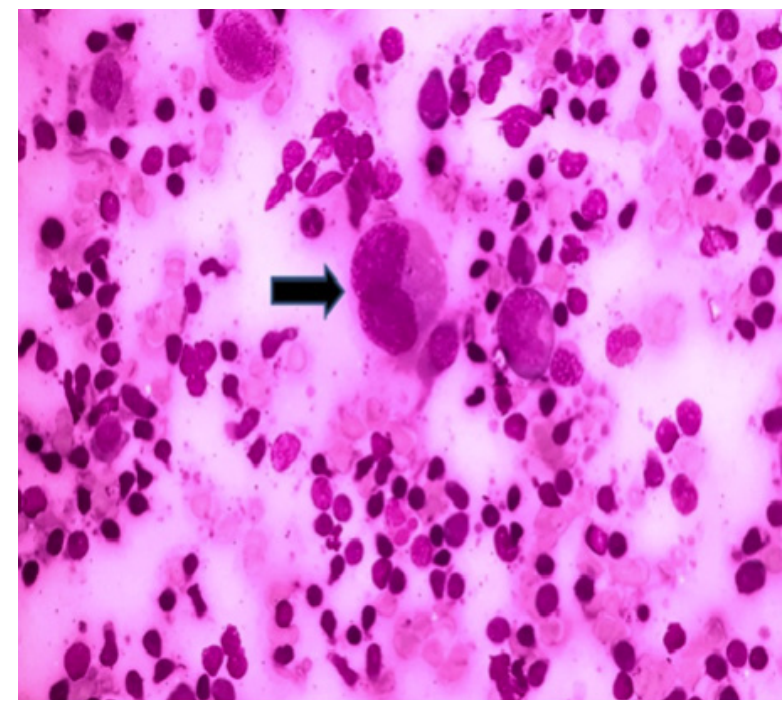

Figure 5: Cytosmear of Hodgkin's Lymphoma showing Reed-Sternberg cell against a background of eosinophils and lymphoid cells (MGG stain, x400)

of non-neoplastic salivary gland lesion with the majority $(\mathrm{n}=8,23.5 \%)$ being reported as benign aspirates which were not having any definite pathology but with benign salivary gland component. In Category IV, among the total $11(32.4 \%)$ benign cases, pleomorphic adenoma (PA) was the dominant $(\mathrm{n}=10,29.4 \%)$ cause of salivary gland swelling (fig. 2) followed by Warthin's tumor ( $\mathrm{n}=1,2.9 \%)$. There was a total of four cases of malignant salivary gland lesions with one case each of adenoid cystic carcinoma (ACC) and mucoepidermoid carcinoma (MEC). The other two malignant cases could not be categorized into definite types due to scant cellularity. There was only one case with suspicion for malignancy under Category $\mathrm{V}$ whereas none were reported as Atypia of Undetermined Significance under Category III (Table 3). A total of five cases of salivary 
gland lesion was sent for HPE, among which all three cases of pleomorphic adenoma were consistent with the cytodiagnosis. One case reported as positive for malignancy on cytology was later diagnosed as cellular pleomorphic adenoma on histopathology and another one case diagnosed as the benign lymphoepithelial cyst was reported as an abscess on cytology.

In the lymph node $(n=150,39.5 \%)$, the majority of the cases were benign $(n=123,82 \%)$ among which reactive lymphadenitis was the commonest $(\mathrm{n}=79,52.6 \%)$ noninfectious cause of lymph node swelling. (Table 4) There were 21 cases $(17.1 \%)$ of tubercular lymphadenitis out of which 15 cases $(71.4 \%)$ demonstrated acid-fast bacilli on $\mathrm{ZN}$ staining and the remaining eight cases were reported as tuberculosis (TB) on the morphological basis of caseous necrosis and epithelioid cell granulomas through the $\mathrm{ZN}$ staining was inconclusive (fig. 3). There was a total of 27 malignant cases (18\%) among which 18 cases $(66.7 \%)$ showed metastatic deposits, the majority $(n=7 ; 38.9 \%)$ being squamous cell carcinoma(Table 4) (fig. 4). A total of 12 cases of lymph node swellings were subjected to HPE out of which 11 cases were consistent with the cytological diagnosis. All five cases of granulomatous lymphadenitis turned out to be tuberculous lymphadenitis and all three cases of Hodgkin's Lymphoma were also consistent with the cyto-diagnosis (fig. 5). However, among the four cases of Non-Hodgkin's Lymphoma (NHL) subjected to HPE, only three cases were consistent with the cyto-diagnosis and one case of NHL was reported with a differential diagnosis of metastatic carcinoma and NHL.

Of the $23(56.1 \%)$ non-neoplastic lesions of the skin, soft tissue and miscellaneous cause of head and neck swellings, epidermal cyst $(n=8,19.5 \%)$, and thyroglossal cyst $(n=8$, $19.5 \%$ ) were the most common lesions whereas, among the benign cases $(n=14,34.1 \%)$, the majority were benign lipomatous lesion (BLL) $(n=9,22 \%)$ followed by spindle cell lesion $(n=2,4.9 \%)$. There was one case each of carotid body tumor, pilomatrixoma, and schwannoma. Out of four malignant cases, three cases were metastatic carcinoma each from the breast, maxillary sinus, and lung as primary malignancy (Table 5). Among the total 41 cases, only seven cases were subjected to HPE and all of them were consistent with the cyto-diagnosis.

Interestingly, in the current study, among the total 380 cases of head and neck swellings, the pediatric population comprised of $42(11.1 \%)$ cases with male predominance $(n=22,52.4 \%)$. All the 42 cases of the pediatric age group had benign and non-neoplastic head and neck lesions largely comprising of $28(66.7 \%)$ cases of reactive lymphadenitis followed by an abscess (14.3\%).

Out of a total of 380 cases of head and neck swelling, 28(7.4\%) cases were available for follow-up and a histopathological examination (HPE) among which 25 (89.3\%) cases were consistent with the cytological diagnosis (Table 6). The sensitivity, specificity, and diagnostic accuracy were evaluated to be $80 \%, 94.4 \%$, and $89.3 \%$ respectively.

\section{DISCUSSION}

FNAC is a valuable diagnostic test in the initial assessment of the patients presenting with a mass in the head and neck region or when a recurrence is suspected after previous treatment. Various parameters like age distribution, sex predilection, site-wise distribution, nature of the lesion, and histopathological correlation wherever possible were evaluated and the findings were compared with other studies.

In this study, the most common site for the occurrence of head and neck masses was from thyroid (40.8\%) which corroborates with the study carried out at a tertiary center in Southern India where the largest number of FNACs were from thyroid constituting $56.45 \%$ of cases. ${ }^{8}$ In contrast to our studies where lymph node swelling is the second common cause of head and neck swelling, the majority of the studies carried out in other parts of Nepal and India show the highest frequency of aspirates from lymph nodes. ${ }^{3,9-12} \mathrm{In}$ the present study, the overall head, and neck swellings were more commonly encountered in females with male to female ratio being 1:2.2 which is similar to other studies. ${ }^{9}{ }^{91-15}$ The peak incidence of head and neck lesions in the majority of the studies was in the second decade, unlike the present study where the lesions were seen in the fourth decade $(18.4 \%))^{9,13,16,17}$

Similar to the studies done by Khetrapal et al, ${ }^{9}$ nonneoplastic lesions were the dominant cause for head and neck swelling in the present study. The majority of the benign and non-neoplastic cases were prevalent in the age groups below 40 years $(50.4 \%)$ whereas the malignant and suspicious cases were seen predominantly in the age groups above 40 years $(73.3 \%)$. Similar findings were observed in the study done by Rathore et al which corroborates with the fact that the advancement of age, genetic aberrations, and prolonged exposure to carcinogenic agents may play role in oncogenesis..$^{10}$

Out of 380 FNAC procedures, $40.8 \%$ of the total cases were thyroid lesion with female preponderance $(83.2 \%)$ with male to female ratio being 1:5 similar to the study done by Prasad. ${ }^{18}$ In contrast, the study done by Rathod and Parmar ${ }^{19}$ showed the ratio as 1:4. Similar to the other studies, the maximum incidence of thyroid lesions in this study was colloid goiter (49.7\%) followed by PCT (7.7\%). ${ }^{11,19,20}$ Singal et al also reported colloid goiter as a dominant disorder in the thyroid region similar to this study. ${ }^{17}$ In the present study, among the total 155 cases of thyroid, only four cases were available for HPE and all the cases were consistent 
with the cyto-diagnosis which is similar to the study done by Pathak et al. ${ }^{11}$ However, in the study conducted by Khetrapal et al, ${ }^{914}$ out of 49 cases were available for HPE and only 12 cases were consistent with the cytological findings and the remaining two cases were inconsistent in which one case reported as colloid goiter on cytology was later on reported as follicular carcinoma and another case as poorly differentiated carcinoma on histology.

Lymph node lesions constitute the second most common cause of head and neck swelling (39.5\%), out of which reactive lymphadenitis was the predominant cytological diagnosis $(52.7 \%)$. Other studies also observed reactive lymphadenitis as the most common diagnosis similar to this study. ${ }^{10,13,17,20,21}$ In the present study female predominance was seen in lymph nodes in contrast to the other studies where there was male predominance. ${ }^{9,11}$ In contrast to our study where TB lymphadenitis was the second most common cause (14\%), few other studies showed TB lymphadenitis as the most frequent cause of lymph node swelling., ${ }^{9,1922-24}$ It is one of the important causes of superficial lymphadenopathy in countries like India and Nepal. Different authors use different criteria for the diagnosis of tuberculous lymphadenitis and the combination of FNAC with ZN staining for $\mathrm{AFB}$ is of the utmost significance as a diagnostic modality. ${ }^{9,13}$ In the present study, the cyto-diagnosis of TB lymphadenitis was based on the morphological findings of caseous necrosis and epithelioid cell granulomas. ZN stain could demonstrate acid-fast bacilli in 15 cases among the 23 cytological cases of granulomatous lymphadenitis with or without caseous necrosis. In contrast to our study, other studies done by Khetrapal et al, Jadhav et al, and Paliwal et al could demonstrate acid-fast bacilli in higher proportion. ${ }^{9,13,25}$

In this study, metastatic squamous cell carcinoma was the commonest (26\%) among the malignant lesion of lymph node swelling, which was comparable with the studies done by Rathore et al and Rathod and Parmar even though the percentage in their studies was higher than in our study. ${ }^{10,19}$

In the present study, among the 12 cases subjected to HPE only one case was inconsistent in which, a case of NHL on cytology was later on reported with differentials of metastatic carcinoma and NHL. Similar to the present study, Khetrapal et al reported 3 cases of inconsistent cyto-histological findings in which one case was reactive lymphadenitis on cytology but later on reported as NHL on histology. ${ }^{9}$

A total of 34 cases of salivary gland lesion of the head and neck swelling underwent FNAC among which the majority of the benign neoplasm was PA (29.4\%) similar to the other studies done by Fernandes et $\mathrm{al},{ }^{8}$ Khetrapal et $\mathrm{al}^{9}$ and Rathod and Parmar. ${ }^{19}$ In the present study, among the total four cases of malignant salivary gland neoplasm, two cases were positive for malignant salivary gland tumor, and one case each was ACC and MEC. In contrast to this study, other studies done in Nepal and India reported MEC as the commonest malignant tumor. ${ }^{8,9,11,19}$

Among the five cases of salivary gland lesion sent for HPE, three cases were PA and all were consistent with the cytodiagnosis. One case reported as positive for malignancy on cytology was later diagnosed as cellular pleomorphic adenoma on histopathology and another one case reported as an abscess on cytology was diagnosed as a benign lymphoepithelial cyst on histology. In a study conducted by Rathore et al, there were two cases of the salivary gland which were inconsistent with the cyto-diagnosis in which one case was suspected as salivary gland malignancy but came out as normal salivary gland tissue on histology, and another case was suspected as metastatic but turned out to be a lymphoepithelial cyst. ${ }^{10}$

Out of $41(10.8 \%)$ cases of skin, soft tissue, and miscellaneous lesions of head and neck swellings, BLL was the commonest lesion(22\%) followed by epidermal cyst $(19.5 \%)$ in accordance to the study by Singal et al ${ }^{17}$ In contrast to our study, Rathore et al, Pathak et al and Suryawanshi et al reported epidermal cyst as a common skin, soft tissue and miscellaneous lesion followed by BLL. ${ }^{10,11,24}$ Among the total 41 cases, only 7 cases were subjected to HPE and all of them were consistent with the cyto-diagnosis. One case was a spindle cell lesion on cytology reported as neurofibroma on histology. Another case was a glioma brain undergoing treatment who presented with swelling of the scalp over the left frontoparietal region involving the bone. It was reported as positive for malignancy on cytology which later on diagnosed as osteosarcoma on histology. As there was no osteoid in between the malignant cells, it was not reported as osteosarcoma on cytology. In a study conducted by Maniyar et al, ${ }^{14}$ cases were subjected to histopathology and all of them showed consistent findings that were similar to this study. ${ }^{3}$

Similar to the study done by Mitra et al our study also showed male predominance $(52.4 \%)$ with lymph node (71.4\%) being the commonest site involved among the head and neck swellings though the percentage of our study was low. In the current study, there were no malignant cases among the pediatric population in contrast to the study done by Mitra et al. which had $11.83 \%$ of malignant cases. ${ }^{22}$

In this study, most of the cases were benign or non-neoplastic and therefore either treated or referred to other centers if it is malignant based on the cytological diagnosis. So, only $28(7.4 \%)$ cases were available for histopathological correlation among which $25(89.3 \%)$ cases were consistent and $3(10.7 \%)$ cases were inconsistent with the cytodiagnosis which is similar to the findings reported by Maniyar et $\mathrm{al}^{3}$ and Khetrapal et $\mathrm{al}^{9}$ Among the total 28 
cases subjected to histopathology, 17 cases were benign and eight cases were malignant whereas one case thought to be as malignant on cytology turned out to be benign on histopathology. The sensitivity, specificity, and diagnostic accuracy were evaluated to be $80 \%$ and $94.4 \%$ respectively in accordance with the other studies done by Fernandes et al8 and Rathore et al ${ }^{10}$

As it is a hospital-based study, it may not represent the population at large. Thus the underrepresentation of cases like Atypia of Undetermined Significance salivary gland and thyroid are likely.

\section{CONCLUSIONS}

The majority of the cases of head and neck swellings were encountered in the thyroid followed by a lymph node, skin, soft tissue, miscellaneous and salivary glands. In thyroid, colloid goiter and papillary carcinoma were the commonest benign and malignant lesions respectively. In lymph nodes, reactive lymphadenitis and metastatic SCC were the commonest benign and malignant lesions respectively. Pleomorphic adenoma was the predominant benign lesion of the salivary gland. The sensitivity, specificity, and diagnostic accuracy were in accordance with the other studies.

\section{Conflict of interest: None}

\section{REFERENCES}

1. Martin H, Ellis EB. Biopsy of needle puncture and aspiration. Ann Surg 1930;92:169-81.

Crossref

2. Orell SR, Sterrett GF. Chapter 1, Introduction. In: Orell SR, Sterrett GF, editor. Manual and Atlas of FNAC. 2nd ed. New York: Churchill Livingstone Elsevier; 2012. p. 1-7. Crossref

3. Maniyar AU, Patel Harshid L, Parmar BH. Study of cytodiagnosis of head and neck neoplastic lesions and comparison with histopathology. Research and reviews: Journal of medical and health sciences 2013;2:54-9. Website

4. EI Hag IA, Chiedozi LC, Al Reyees FA, et al. Fine needle aspiration cytology of head and neck masses. Seven years' experience in a secondary care hospital. Acta Cytol 2003;47:387-92. Crossref

5. Florentine BD, Staymates B, Rabadi M, et al. Cancer Committee of the Henry Mayo Newhall Memorial Hospital. The reliability of fine-needle aspiration biopsy as the initial diagnostic procedure for palpable masses: A 4-year experience of 730 patients from a community hospital-based outpatient aspiration biopsy clinic. Cancer 2006;107:406-16. Crossref
6. Batra M, Madhwa N, Mishra K. Cytologic diagnosis in benign odontogenic tumor with abundant calcification: A case report. Acta Cytol 2009;53:460-2. $\underline{\text { Crossref }}$

7. Carrillo J, Ramirez R, Flores L, et al. Diagnostic accuracy of fine needle aspiration biopsy in preoperative diagnosis of patients with parotid gland masses. J Surg Oncol 2009;100:133-8. $\underline{\text { Crossref }}$

8. Fernandes H, D'Souza CRS, Thejaswini BN. Role of Fine needle aspiration cytology in palpable head and neck masses. J Clin Diag Res 2009;3:1717-25. Website

9. Khetrapal S, Jetley S, Jairajpuri Z, et al. FNAC of head \& neck lesions and its utility in clinical diagnosis: A study of 290 cases. Nat J Med Res 2015;5:33-8. (Corpus ID: 53326028) Website

10. Rathore H, Jethani N, Pachori G, et al. Cytomorphology of head and neck lesions: A study in tertiary care hospital. Panacea J Med Sci 2015;5:145-9. $\underline{\text { Website }}$

11. Pathak R, Prasad KBR, Rauniyar SK, et al. Fine needle aspiration cytology of head and neck lesions and its correlation with histopathology. J Pathol Nep 2016;6:985-9. Crossref

12. Banstola L, Sharma S, Gautam B. Fine needle aspiration cytology of various head and neck swellings. Medical Journal of Pokhara Academy of Health Sciences 2018;1:836. $\underline{\text { Crossref }}$

13. Jadhav DS, Barge AK, Valand AG. Study of fine needle aspiration cytology of palpable head and neck lesions in tertiary care centre. Ind J Pathol and Oncol 2018;5:375-81. Crossref

14. Muddegowda PH, Srinivasan S, Lingegowda JB, et al. Spectrum of cytology of neck lesions: Comparative study from two centers. J Clin Diagn Res 2014;8:44-5. $\underline{\text { Crossref }}$

15. Valiya LG, Padhariya BB, Baxi SN. Spectrum of FNAC in palpable head and neck lesions in a tertiary care hospital in western India- A 2 years study. IOSR J Dent Med Sci 2016;15:14-9. Website

16. Gogoi G, Borgohain D. FNAC on palpable neck massesA hospital based study. Indian J Appl Res 2016;6:39-42. $\underline{\text { Website }}$

17. Singal P, Bal MS, Kharbanda J, et al. Efficacy of fine needle aspiration cytology in head and neck lesions Int $J$ Med Dent Sci 2014;3:421-30. Crossref 
18. PraneshPrasad.ComparativestudyofFNACandhistopathology in diagnosis of thyroid swellings. Indian J Surg 1992;54:287-91. Crossref

19. Rathod GB, Parmar P. Fine needle aspiration cytology of swellings of head and neck region. Indian J Med Sci 2012;66:49-54. Crossref

20. Rajbhandari $\mathrm{M}$, Dhakal $\mathrm{P}$, Shrestha $\mathrm{S}$ et al. The correlation between fine needle aspiration cytology and histopathology of head and neck lesions in Kathmandu University hospital. Kathmandu Univ Med J 2013;11:296-9. Crossref

21. Mainali N, Suwal RB. Patterns of lymphadenopathy on fine needle aspiration cytology in eastern Nepal. J Pathol Nep 2015;5:814-6. Crossref

22. Mittra P, Bharti R, Pandey MK. Role of fine needle aspiration cytology in head and neck lesions of paediatric age group. J Clin Diagn Res 2013;7:1055-8. Crossref
23. Poorey VK, Tyagi A. Accuracy of fine needle aspiration cytology in head and neck masses. Indian J Otolaryngol Head Neck Surg 2014;66:182-6. Crossref

24. Suryawanshi KH, Damle RP, Nikumbh DB, et al. Cytohistopathological correlations of head and neck swellings in a rural hospital in north Maharashtra: our experience. Ann Pathol Lab Med 2015;2:121-6. (Corpus ID: 56064492) Website

25. Paliwal N, Thakur S, Mullick S, et al. FNAC in tuberculous lymphadenitis: Experience from a tertiary level referral centre. Ind J Tuberc 2011;58:102-7. Website 